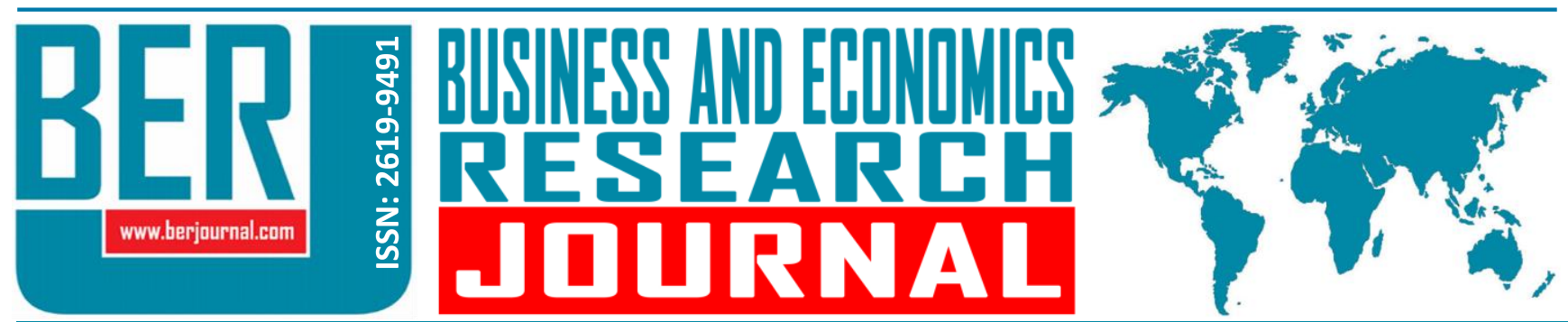

Business and Economics Research Journal Vol. 9, No. 3, 2018, pp. 715-733 doi: 10.20409/berj.2018.133

\title{
An Analysis on Domestic Violence against Women in Turkey: Multinomial Logit Model
}

\author{
Ozlem Ayvaz Kizilgol ${ }^{\mathrm{a}}$, Evren Ipek
}

Abstract: The present study empirically evaluates the socio-economic factors that affect the domestic violence against women in Turkey. The types of violence against women was examined with the Multinomial Logit Model (MNLM) by the use of data received from the Survey on Domestic Violence against Women in Turkey, which was performed by Turkish Statistical Institute for the year 2014. Empirical results show that physical and sexual violence raises as the women's age increase; and if the educational status of the women and their husbands was at and above university level, women faced less domestic violence. The results indicate that employment of women and husband did not have any significant effects on physical violence and economic and emotional violence. It is observed that if women had their own income or earning, they received less economic and emotional violence; and health insurance for women reduced the possibility of all types of violence. The results reveal that women living in urban areas were exposed to any type of violence more than those living in rural areas; and the bad habits of spouse (alcohol, gambling and drugs) increased every type of violence against women.

Keywords: Domestic Violence against Turkish Women, Physical Violence, Sexual Violence, Economic and Emotional Violence, MNLM

JEL: D63, J12, C25
Received : 03 May 2018

Revised : 29 May 2018

Accepted : 06 June 2018

Type : Research

\section{Introduction}

Violence against women is a very important social problem and a violation of human rights both in the world and in Turkey. In the Declaration on Dissolving Violence Against Women, which was released in 1993 by United Nations General Council, the term "violence against women" was defined as "Any act based on gender that might occur in public or in private live, which might harm and cause pain in physical, sexual or psychological terms, including the threats on depriving women of their freedom in a compulsory and arbitrary manner". In this declaration, it is emphasized that violence against women is the violation of basic rights and freedoms of women; and it is stated that such violence reflects the imbalance between women and men, which has continued throughout history; and it is accepted that this is a type of discrimination against women.

UNICEF (2000) defined domestic violence as the violence coming from the spouse, from the partner or from other individuals in the family no matter within the borders of the house or not. Domestic violence denotes the violence or harassment to each other in house, which is established for reasons like marriage or living together. Domestic violence may occur in various forms such as physical, sexual and emotional. Since

a Asst. Prof., PhD., Bandırma Onyedi Eylül University, Faculty of Economics and Administrative Sciences, Department of Econometrics, Balıkesir, Turkiye, okizilgol@bandirma.edu.tr (ORCID ID: 0000-0001-9996-7892)

b Asst. Prof., PhD., Bandırma Onyedi Eylül University, Faculty of Economics and Administrative Sciences, Department of Economics, Balıkesir, Turkiye, eipek@bandirma.edu.tr (ORCID ID: 0000-0003-4855-6545) 
domestic violence may be applied to children, it is more comprehensive definition than the violence against spouse (Dasre, Greulich \& Inan, 2017: 6).

According to the data released by the World Health Organization, one out of every three women throughout the world (30\%) faces physical or sexual violence by her husband or partner she lives with. It was observed that this rate goes up to $38 \%$ in some areas. In addition, it is another important issue that must be emphasized that women murders are caused by their husbands at a rate of $38 \%{ }^{1}$

According to the "Domestic Violence against Women in Turkey Survey" conducted by Hacettepe University Institute of Population Studies and TURKSTAT in 2014, the rate of the women who stated that they faced physical violence from their husbands or the spouse they lived with was $36 \%$ in Turkey. This situation means that nearly 4 out of every 10 women face physical violence from their husbands or partners they live with. Throughout Turkey, the rate of the women who faced physical violence by their husbands or partners they live with within the past 12 months was $8 \%$. The highest rates in terms of physical violence both in any period of life and in the past 12 months was determined in the Central Anatolian Region (43\% and 11\%). 12\% of the married women in Turkey stated that they faced sexual violence in any period of their lives and $5 \%$ stated that they faced sexual violence in the past 12 months. The region where sexual violence was reported at the highest rate was the Northeastern Anatolian Region for both periods ( $16 \%$ and $8 \%$ ). In addition, $38 \%$ of the ever married women throughout Turkey faced physical and/or sexual violence in any period of their lives. In the past 12 months, this rate was $11 \%$. The most frequently observed violence type faced among women is emotional violence. The rate of the women who stated that they faced emotional violence in any period of their lives throughout Turkey was $44 \%$, and $26 \%$ in the past 12 months. Economic violence has been defined as preventing women from working, causing them to leave their jobs, not giving money for domestic expenses, or taking the income or earnings of women from them. Throughout Turkey, the rate of the women who stated that they faced at least one of these behaviors in any period of their lives was $30 \%$, and the rate of women who stated that they were exposed to these kind of violence in the past 12 months was $15 \%$. The most frequently reported violence type among the economic violence was preventing women from working or causing that they leave their jobs. Another result of the present study was that $44 \%$ of the women in Turkey who faced violence from their husbands or partners they lived with did not tell the violent behaviors to anybody before.

The role of the androcentric structure of the Turkish society is big in the violence against women in Turkey. "Man is a man. He both loves and beats", "Those who do not beat their daughters beat their laps", "You should not deprive women from a stick on their back and a kid in their belly", "Do not interfere between wife and husband", and many other proverbs may be given as examples to show how violence against women is normalized in our society. Another important point here is that women who receive domestic violence in Turkey usually hide the violence because they are embarrassed. In this hiding, women's feeling that the guilt is theirs and the fear of being shun in case it is heard have important roles (Oktay, 2015: 59). Based on this, it will not be wrong to claim that the real numbers are much higher than these figures obtained in research conducted on domestic violence against women.

There are many cultural, economic, legal and political elements that cause violence against women, and the socio-economic costs of the violence are also high on individuals, families and the society ${ }^{2}$. As previously conducted studies report, domestic violence may harm women in physical and emotional terms at an important level, and affect negatively their employment status, productivity in working life, and their participation in social life. In addition, through the children who witness domestic violence, the negative effects of violence are transferred among generations. In addition, it must not be ignored that domestic violence has important economic costs as well (Panda \& Agarwal, 2005: 824). For example, in Chile, the salary losses of women due to domestic violence against women was 1.56 billion Dollars, and it was determined that this rate was more than $2 \%$ of the GNP of the country. The cost of the violence faced by women from their husbands in the USA exceeded 5.8 billion Dollars in annual scale. Preventing violence against women will decrease the state expenses and increase productivity. Despite the importance of this issue in ensuring development in a country, violence based on gender is not included in the strategies that are being developed to increase economic growth (Beavers \& Kumpf, 2013). 
It has been accepted generally that the development in a country must be considered not only in terms of economic growth, but also in terms of the improvements in human capabilities. If development is defined as the expansion of human capabilities, freedom from domestic violence must be handled as an important element in the evaluation of development (Panda and Agarwal, 2005). Decreasing the spread of domestic violence against women must be an important political target.

In the present study, the aim was to investigate the factors that affected domestic violence against women in Turkey in an empirical manner. The empirical analyses of the study were performed by using the raw data of the "Domestic Violence against Women in Turkey Survey" conducted by TURKSTAT in Turkey in 2014. In this context, the present study will contribute to the literature with the empirical analyses conducted with the most recent data. The further parts of the study are organized as follows; the second section summarizes the empirical literature on the determinants of the violence against women; the third section introduces the dataset and the variables used in the empirical analyses; and exhibits the empirical results after evaluating descriptive statistics; and fourth section includes conclusions and recommendations.

\section{Literature Review}

In this section of the study, various empirical studies that analyzed the determinants of the domestic violence against women will be evaluated. Sorenson, Upchurch and Shen (1996) investigated the victimization, violence and injury in marital arguments for United States. The authors used the cross-sectional data of the "National Survey of Families and Household", which covered the March 1987 - May 1988 period. They applied binary logit and MNLM methodology to analyze the properties of those who faced physical violence and to determine who was guilty and who was innocent. It was observed that women and men showed similar behaviors in verbal arguments. It was reported that young people, those who resided in urban areas, those who had low income or earning levels and the black persons faced physical violence more in their marriages. They also found out that ethnical origin, income or earning levels, education, the number of children in family, the ages of children were not related with the injury of women, men or both. It was also reported in this study that persons who faced physical violence in their marriage are very similar to those who are at increased risk of interpersonal violence in general.

Panda and Agarwal (2005) put forth a study for India. Although they focused on the effects of women's property status on the violence they faced during marriage, they also investigated the effects of the economic structure of the family, socio-demographic features, education and employment status of women and their husbands, the social support for women, the case whether the women and their husband witnessed domestic violence in their childhood, and alcohol use of husbands. Their study was based on the questionnaires that were conducted with 502 ever married women (between the ages of 15-49) in 2001 in Kerala State of India. The empirical examinations were performed with Logit Model. It was determined that women's property ownership affected physical and psychological violence negatively at a significant level. As the cause of these findings, it was emphasized that property ownership increased the negotiation power of women in marriage; and decreased the tolerance of women to violence. In addition to these findings, it was also determined that the social support from family or neighbors, the income or earning level of the household, and the employment of husband had significant effects on the decrease of violence against women. The employment of women decreased the risk of facing physical violence in the long run only if the job was a regular work. Another finding of the study was that husbands' witnessing violence to their mothers by their fathers during their childhood affected the physical and psychological violence against women positively and significantly.

Ergin, Bayram, Alper, Selimoğlu and Bilgel (2005) investigated the prevalence, frequency, types and reasons of marital violence against woman in a metropolitan city of Turkey (Bursa). The empirical applications were based on horizontal cross-sectional data in 2003. The study included fifty married women who visited community clinics for different reasons and who were at and above the age of 18. 1010 of the 1427 questionnaires were found appropriate; and the questionnaires were supplemented with face-to-face interviews. The Multiple Correspondence Analysis and Logistics Regression Analysis were applied in the study. A statistically significant relation was found between domestic violence and educational level. Women 
with no education were exposed to violence more than those who were university-graduates or who had higher degrees at a rate of 2.6 times more. No statistically significant relation was found between the age, job status, marriage duration or family income or earning level and domestic violence. The most frequent violence type was physical violence followed by emotional violence. The importance of educating girls was emphasized in preventing domestic violence.

Kocacık and Doğan (2006) investigated the reasons of violence against women for the city of Sivas. The analyses were based on the findings that were obtained from the questionnaires applied to 583 household selected from 10 neighborhoods in 2004. According to the results, the rate of the domestic violence was $52 \%$. They determined that as the annual income level of the family increased, the rates of domestic violence decreased. Low educational level was found to be an important element that increased domestic violence. It was also determined that $74 \%$ of the women who were exposed to violence were housewives. Based on this result, the importance of the protective effects of economic freedom in the face of domestic violence was emphasized.

Kocacık, Kutlar and Erselcan (2007) performed empirical evaluations with the Logit Model in Turkey by focusing on four cities; Kırklareli, Adıyaman, Denizli, and Sivas. The model in which the prevalence of domestic violence against women was the dependent variable included several independent variables such as: age of woman, education level of the woman, marital status, number of children, employment status of the woman, personal income or earnings of the woman, employment status of the spouse, income or earnings of the household, type of the family, house ownership, and neighborhood. The findings that were obtained from interviews with 670 women in March-May period of the year 2002 showed that $27.5 \%$ of the women who were included in the study faced domestic violence. The results of the empirical analyses may be summarized as follows; (i) the prevalence of women younger than 20 years of age facing violence was higher than the other age groups; (ii) university graduates faced less violence than those who did not have any education; (iii) the probability of working women being exposed to violence was nearly 3 times more than those who did not work; (iv) the women who stated that their husbands dealt with trade were exposed to violence at a rate of nearly 2 times more than those whose husbands did not work; $(v)$ violence was faced less by women living in families who were in a better environment in social terms; (vi) there was a positive ship between the income or earning level of the family and the domestic violence; (vii) as the number of the children increased, the violence against women increased as well; (viii) most probably, women who faced violence when they were children also received violence when they grew up; (ix) women received more violence in families where intra-family decisions were made under the dominance of the husbands; $(x)$ the frequency of women facing violence increased when women had to take permission from their husband for some activities.

Altınay and Arat (2009) conducted a study that based on findings from face-to-face interviews with 1800 ever married women living in 56 cities in Turkey. The aim of the study was to determine the reasons for domestic violence faced by women from their spouses. They indicated that generally one of every three women (35\%) throughout Turkey were exposed to violence by their husbands. According to the results of the questionnaires, $49 \%$ of women who were exposed to violence stated that they never shared this issue with anybody before. The results revealed that there is a negative relationship between the violence and the educational level of women, the educational level of the husband, the income or earning level of the family and. It was determined that in case women had income or earning levels more than their husbands, the risk of being exposed to violence increased. Another important finding on the economic violence faced by women was that: $36 \%$ women that are not employed thought that if they demand to work at a job to receive income, they would be refused by their husbands.

Friedemann-Sánchez and Lovatón (2012), in their analyses for Colombia, investigated the violence applied to women by the person they lived with by using the data of the Survey of Demographical Health for the year 2005. They examined the presence of physical and emotional violence and the relevant risk factors by making evaluations on the interviews with the household, and by using the a bivariate Probit Model, and by considering the variables like the income or earning levels, the decisions based on gender made within the family, employment, migration due to armed conflict and maltreatment. The results of the study 
emphasized especially that the maltreatment faced during childhood had effects on domestic violence. The results of this study also revealed that there was a need for lifelong policies for families. It is recommended to policy-makers and researchers to take applicable, theoretical and methodological precautions.

Yüksel-Kaptanoğlu, Türkyılmaz and Heise (2012) conducted a study and examined the determinants of physical and sexual violence faced by ever married women between the ages of 15-49 in Turkey. According to the analysis results performed with the Logit Model, there is a significant and positive relationship between the violence faced by women from their husbands and the violence experiences witnessed by women or their husbands during childhood years. In addition to these, it was also determined that the marriages on whom the families decided, the alcohol use and adultery of the husband, and the unwillingness of the husband on seeing women's friends and family were the factors that increased violence at a significant level. The age of women, the contribution of women to the family income or earning, the support of the family of the women, women's accepting the authority of their husband, and regional differences were also determined to be the factors that affected the risk of violence. No significant relation was determined between the employment status of women and their husbands and the violence they received.

Büyükyılmaz and Demir (2016) evaluated the factors that affected domestic violence against women in Turkey with the MNLM analysis. In empirical analyses, the "Domestic Violence against women in Turkey Survey" dataset released by TURKSTAT for the year 2008 was used. According to the data received from the questionnaires applied to 2071 women between $15-59$ years of age, two different modellings were used by comparing those who faced physical violence with those who do not experience any violence; those who experienced sexual and physical violence and those who did not experience any violence. According to the results obtained, those who graduated high-school and upper education levels faced less violence than those who were primary school graduates; those who were 26 years old and above faced less violence than those who were between 14-25 age group; those whose spouses received high school and upper education faced less violence than those whose spouses were primary school graduates; those whose spouses work faced less violence than those whose spouses did not work; those whose spouses did not use alcohol faced less violence than those whose spouses used alcohol; those who lived in Marmara Region faced less violence than those who lived in Central Anatolia, Eastern and Southeastern Anatolia Regions. These findings are supported by the second model in which those who received both physical and sexual violence were included.

Arı and Aydın (2016) investigated the factors that affected domestic violence against women in Turkey with MNLM methodology. In the analyses, the data of the "Domestic Violence against women in Turkey Survey", which was conducted in 2008 by TURKSTAT, were used. The questionnaire used in this study were performed with 12795 women in Turkey. The dependent variables were determined in 4 categories as those who faced physical violence, those who faced sexual violence, those who faced physical and sexual violence, and those who faced no violence. According to the empirical findings obtained in the study; (i) the risk of facing physical, sexual and both physical and sexual violence by the participants who lived in the Eastern region of the country was higher than those who lived in other regions; (ii) the probability of facing physical violence in women between 43-59 years of age was higher than those of other age groups; (iii) the rate of women who received no education in terms of facing violence was higher than those from other educational levels; (iv) the probability of facing violence by women whose spouses were graduated from secondary schools was higher than those whose spouses were from other educational levels; $(v)$ the probability of facing violence by women whose spouses worked at industrial sector was lower than the women whose spouses worked at other sectors; (vi) the increase in the frequency of alcohol use and gambling of the husband increased the probability of facing physical and sexual violence of women; (vii) the probability of facing physical, sexual and both physical and sexual violence was higher in women who think that their spouses were cheating them; (viii) the probability of facing physical and sexual violence against women who were relatives with their spouses was higher than women who were not relatives with their husbands; (ix) the probability of facing physical and sexual violence for women whose husbands did not receive any education was higher than women whose husbands were from other educational levels.

Ksuthan, Mwaba and Menon (2016) conducted a study for Zambia and analyzed the factors that affected domestic violence with the Logistic Regression Model. The sampling of the study included 7146 ever 
married women. The data of the study were received from the Zambia Demographic Health Survey, which was performed in 2007. In this study, $43 \%$ of the participants stated that they faced a physical violence experience in their lives. According to the analysis results; (i) women living in rural areas faced physical and emotional violence more than women living in urban areas at a rate of 1.9 times; (ii) women living in rural areas faced more sexual violence than women living in urban areas; (iii) it was determined in this study that as the educational level of the husbands increased, physical violence decreased, and as the educational level of women increased from primary school to secondary education, physical violence increased; (iv) the alcohol use of husbands was determined as a factor that increased physical, emotional and sexual violence; (v) the probability of facing physical violence for women whose marriage durations were between 5-14 years was higher when compared with women whose marriage durations were lower; (vi) women whose economic status was at middle level faced more physical and emotional violence when compared with women whose economic status was lower; (vii) the probability of facing emotional violence was higher in women who were married for more than 10 years; (viii) working women faced more emotional and sexual violence when compared with women who did not work at a rate of 1.6 times; (ix) it was also determined in this study that as the educational level increased in women, they faced more emotional and sexual violence; $(x)$ the risk of facing sexual violence increased as the marriage duration increased.

Dasre, Greulich and Inan (2017) investigated the effects of economic contribution of women on domestic violence for Turkey. They focused on ever married women who were between the ages of 15-59 and made use of the "Domestic Violence against Women Questionnaire", which was conducted in 2014. The concept "domestic violence" was considered as the physical and/or sexual violence applied by the husband/the men who were in close intimacy for the past 12 months. In empirical analyses, the Logit Model was used. In the analyses, the authors focused on the effects of the empowering women in socio-economic terms (which was measured with the "education of women, their participation in labor force, and their contribution to the family income or earnings" variables). They found that higher educational level and the employment in official jobs protected women from domestic violence. However, it was also observed in this study that the unequal distribution of the economic power in the family had the potential of creating tension that might end up with domestic violence. The details on the results of the analyses may be summarized as follows; (i) as the age and marriage age of women increased, the probability of facing violence decreased; (ii) as the number of children increased, the probability of facing violence increased; (iii) the probability of facing violence was higher for women who married without their consents and who remarried; (iv) they found a positive relation between the alcohol use of the husband and violence; $(v)$ the risk of facing violence for women who had higher educational level was lower; (vi) the probability of facing violence for women who were employed in irregular jobs or non-official jobs was higher than women who worked in official jobs or who were not active in business life.

Yilmaz (2017) empirically analyzed the relationship between the violence faced by women from the man who was in close intimacy with them and the authority of women in decision-making processes in the family for Turkey. The Turkey Household Structure Questionnaire (2006) was made use of in performing the analyses. The sampling of the study consisted of 6435 couples. The IRT (Item Response Theory) Model was used in the analyses. According to the results obtained from the study, violence had a significant and negative effect on the authority of women. As the violence against women increased, the authority of women decreased. However, it was also determined that the increase in the authority of women decreased the violence against women. Another finding of this study was that the educational status and the presence of personal income or earnings of women affected the authority of women in the family in a significant and positive way.

\section{Multinomial Logit Model}

MNLM is commonly used in social researches in order to analyze the nominal categorical dependent variables. This model can be considered as simultaneous estimates of binary logit models for all possible comparisons of categories of dependent variables. MNLM is an extended version of binary logit model for choices more than two (Büyükyılmaz \& Demir, 2016: 444). MNLM is estimated with maximum likelihood 
method like in binary logit models. And it is assumed that the alternative options that generate dependent variable of the model are independent from each other (Greene, 2012). The estimates obtained from binary logit model provide consistent estimates of the parameters of MNLM. MNLM does not assume normality, linearity and homoscedasticity assumptions. The MNLM estimates the effect of the explanatory variables on a dependent variable with non-ordered output (nominal categorical) (Selim, 2008: 347). The individual prefer the option that maximizes the benefit among the alternatives. According to the model, the possibility of the individual to choose any of the alternative options can be expressed as:

$$
\operatorname{Pr} o b(y=j)=\frac{e^{\sum_{k=1}^{K} \beta_{j k} X_{k}}}{1+\sum_{j=1}^{J-1} e^{\sum_{k=1}^{K} \beta_{j k} X_{k}}}
$$

Equation (1) indicates $\operatorname{Pr} o b(y=j)$ for $j=1,2, \ldots \ldots \ldots . . . J-1 \quad$. It demonstrates the probability of $\mathrm{i}$. individual to prefer the $\mathrm{j}$. alternative. $\mathrm{Y}$ symbolizes dependent variable, $\mathrm{X}$ symbolizes the vector of independent variables and $\beta$ symbolizes the parameter vector to be estimated. $\beta$ parameters in the model have two indices. $k$ is the indice that represents the $x$ independent variables and $j$ is the indice that represents the dependent variable categories. The $\mathrm{j}$ indice indicates that the total number of parameter estimates will be $(\mathrm{J}-1) \mathrm{K}$. Sample size must be greater than $(\mathrm{J}-1) \mathrm{K}$ (Selim, 2008: 348). In estimating the model, one of the alternatives is taken as base or reference and the parameter estimators are obtained by maximizing the loglikelihood function (Darıcı \& Taşşı, 2015: 23).

MNLM is valid under the assumption of Independence of Irrelevant Alternatives (IIA). The independency between alternatives is defined as the independence of the selected alternative from the relevant possibilities of other alternatives selected. MNLM also assumes that deviations are independent. According to this model (Selim, 2008: 348):

$$
\frac{P_{i j}}{P_{i k}}=\frac{e^{\bar{U}_{i j}}}{e^{\overline{u_{i k}}}} \quad \text { and } \quad \ln \frac{P_{i j}}{P_{i k}}=\bar{U}_{i j}-\bar{U}_{i k}
$$

the odds ratio which is represented in Equation 2 is not influenced by the existence of a third alternative. The IIA hypothesis is tested by the Hausman test developed by Hausman and McFadden (1984). The Hausman test compares the restricted model obtained by subtracting at least one of the dependent variable categories with the unrestricted model estimates covering all categories of the dependent variable (Long, 1997: 184). If the difference between these two models is significant, the IIA assumption is not valid. The Hausman test statistic is as follows:

$$
\chi^{2}=\left(\hat{\beta}_{s}-\hat{\beta}_{f}\right)^{\prime}\left[\hat{V}_{s}-\hat{V}_{f}\right]^{-1}\left(\hat{\beta}_{s}-\hat{\beta}_{f}\right)
$$

$\hat{\beta}_{s}$ is the estimate of restricted model and $\hat{\beta}_{f}$ is the estimate of unrestricted model. $\hat{V}_{s}$ and $\hat{V}_{f}$ are respectively asymptotic covariance matrices of restricted and unrestricted models (Selim, 2008: 348).

\section{Empirical Analysis}

\subsection{The Data and the Variables Used}

This study investigated the factors that affected the probability of domestic violence against women. In empirical analyses, we used the raw data of "National Research on Domestic Violence against Women in Turkey", which was conducted in 2014 by TURKSTAT. The first comprehensive study conducted on violence against women that has the quality of representing the whole country was "National Research on Domestic Violence Against Women in Turkey 2008", which was conducted by TURKSTAT. The "National Research on 
Domestic Violence against Women in Turkey 2014" was the second survey that represented the whole country with the widest sampling and it was conducted for the purpose of understanding the dimensions, reasons, contents, results and the relevant risk factors of the domestic violence faced by women (TURKSTAT). The research was conducted with 7462 women between the ages of 15-59. However, since 669 women did not answer the questions that were used in forming the violence types, the analyses were performed by using the information obtained from 6793 participants. In addition; since women left the question which included many variables unanswered, only the variables given in Table 4 were used in the analyses. The violence types faced by women were measured as four qualitative variables which were "Those who do not experience any violence", "Those who experience physical violence", "Those who experience sexual violence" and "Those who experience both economic and emotional violence". These violence types were formed by grouping the questions in the questionnaires according to the definition for violence types of TURKSTAT. The survey questions that were used in forming the violence types are given in Table 5 in Appendices section. The analyses were performed with MNLM methodology.

\subsection{Descriptive Statistics}

The descriptive statistics on the variables obtained from the database which consisted of 6793 women between the ages 15-59 are given in Table 4. When Table 4 is analyzed, it was determined that the women between 15-25 age group had the lowest percentage (15\%) among the women who participated in the study; and women between $26-35$ age group had the highest percentage (31\%). Approximately $72 \%$ of the women were those who did not go to school or who were primary school graduates; while the rate of those who were high school graduates was approximately $17 \%$, and the rate of those who were graduated from university and above educational levels was $11 \%$. Among the women who participated in the study, $31 \%$ were employed, and $69 \%$ were unemployed. When the health insurance of the participants was considered, it was determined that 6007 (88\%) of the women had health insurance, while $786 \%(12 \%)$ of them did not have this opportunity. $24 \%$ of the women had their own income or earnings; however, approximately $76 \%$ of them did not have any income or earnings. When the educational level of the husbands was considered, it was determined that the husbands of $59 \%$ of the women who answered the questionnaire did not attend any schools or were primary school graduates; and the husbands of only $16 \%$ of the women were university and above level graduates. The rate of those whose husbands worked was $81 \%$, and the rate of those whose husbands did not work was $29 \%$. When the alcohol, gambling and drug use habits of the husbands or the person women lived with were investigated it was determined that $20 \%$ used alcohol, $2 \%$ had gambling habits and $0.6 \%$ used drugs. According to residential area status, approximately $69 \%$ of the women lived in urban areas, while $31 \%$ lived in rural areas. In terms of having children, it was determined that $45 \%$ of the women who participated in the questionnaire had children between 6-14 age group. On the other hand, $56 \%$ did not have any children between these ages.

Table 6 provides the frequency distribution of the violence types faced by women. The rate of those who faced physical violence was approximately $24 \%$, the rate of those who faced sexual violence was $11 \%$, the rate of those who faced economic and emotional violence was $22 \%$. Approximately $43 \%$ of the women who completed the questionnaire stated that they never faced violence. 
O. Ayvaz-Kizilgol - E. Ipek

Table 1. Descriptive Statistics

\begin{tabular}{|c|c|c|c|c|c|}
\hline & $\mathbf{N}$ & Mean & Std. Dev. & Min. & Max. \\
\hline Violence Types & 6793 & 1.131 & 1.191 & 1 & 4 \\
\hline \multicolumn{6}{|l|}{ Woman's age } \\
\hline $15-25$ & 1021 & 0.150 & 0.357 & 0 & 1 \\
\hline $26-35$ & 2115 & 0.311 & 0.463 & 0 & 1 \\
\hline $36-45$ & 1784 & 0.263 & 0.440 & 0 & 1 \\
\hline $46-59$ & 1873 & 0.276 & 0.447 & 0 & 1 \\
\hline \multicolumn{6}{|l|}{ Educational level of woman } \\
\hline No education or primary school & 4884 & 0.719 & 0.450 & 0 & 1 \\
\hline High school & 1143 & 0.168 & 0.374 & 0 & 1 \\
\hline $\begin{array}{l}\text { Graduated from university and above } \\
\text { educational levels }\end{array}$ & 766 & 0.113 & 0.316 & 0 & 1 \\
\hline \multicolumn{6}{|l|}{ Employment status of woman } \\
\hline Working & 2121 & 0.312 & 0.463 & 0 & 1 \\
\hline Not working & 4672 & 0.688 & 0.463 & 0 & 1 \\
\hline \multicolumn{6}{|l|}{ Woman has health insurance } \\
\hline Yes & 6007 & 0.884 & 0.320 & 0 & 1 \\
\hline No & 786 & 0.116 & 0.320 & 0 & 1 \\
\hline \multicolumn{6}{|l|}{ Woman has own income or earnings } \\
\hline Yes & 1658 & 0.244 & 0.430 & 0 & 1 \\
\hline No & 5135 & 0.756 & 0.430 & 0 & 1 \\
\hline \multicolumn{6}{|l|}{ Educational level of husband/partner } \\
\hline No education or primary school & 4015 & 0.591 & 0.492 & 0 & 1 \\
\hline High school & 1668 & 0.246 & 0.430 & 0 & 1 \\
\hline $\begin{array}{l}\text { Graduated from university and above } \\
\text { educational levels }\end{array}$ & 1110 & 0.163 & 0.370 & 0 & 1 \\
\hline \multicolumn{6}{|l|}{ Employment status of husband/partner } \\
\hline Working & 5465 & 0.805 & 0.397 & 0 & 1 \\
\hline Not working & 1328 & 0.195 & 0.397 & 0 & 1 \\
\hline \multicolumn{6}{|l|}{ Husband/Partner uses alcohol } \\
\hline Yes & 1365 & 0.201 & 0.401 & 0 & 1 \\
\hline No & 5428 & 0.799 & 0.401 & 0 & 1 \\
\hline \multicolumn{6}{|l|}{ Husband/Partner gambles } \\
\hline Yes & 136 & 0.020 & 0.140 & 0 & 1 \\
\hline No & 6657 & 0.980 & 0.140 & 0 & 1 \\
\hline \multicolumn{6}{|l|}{ Husband/Partner uses drug } \\
\hline Yes & 42 & 0.006 & 0.784 & 0 & 1 \\
\hline No & 6751 & 0.994 & 0.784 & 0 & 1 \\
\hline \multicolumn{6}{|l|}{ Place of residence } \\
\hline Urban & 4662 & 0.686 & 0.464 & 0 & 1 \\
\hline Rural & 2131 & 0.314 & 0.464 & 0 & 1 \\
\hline \multicolumn{6}{|l|}{ Child between 6-14 } \\
\hline Exist & 3026 & 0.445 & 0.497 & 0 & 1 \\
\hline Absent & 3767 & 0.555 & 0.497 & 0 & 1 \\
\hline
\end{tabular}

Table 6. Frequency Distribution of Violence Types

\begin{tabular}{|l|l|l|}
\hline Types of violence & Frequency & Percentage \\
\hline Never seen violence & 2910 & 42.84 \\
\hline Physical & 1611 & 23.72 \\
\hline Sexual & 747 & 11.00 \\
\hline Economic and Emotional & 1525 & 22.45 \\
\hline Total & 6793 & 100 \\
\hline
\end{tabular}




\subsection{Model Estimations}

In the present study, the types of the violence against women were classified under four categories as "Those who do not experience any violence", "Those who experience physical violence", "Those who experience sexual violence" and "Those who experience both economic and emotional violence". For this reason, it is not possible to make a ranking like the dependent variables used in the study were categorical or qualitative and no direct ranking is possible like better or worse among alternative options. In situations when dependent variable is defined like this, multiple choice models are used in the literature. The MNLM was used in this present study. The estimation results of the MNLM, which was formed to reveal the determinants of the domestic violence against women, are given in Table 7. The reference category was identified as "Those who do not experience any violence". In the models given in Table 7, the first column gives the coefficient values, the second column gives the Relative Risk Ratios (RRR), and the third column gives the probability values. The values of the relative risk ratios have always positive signs; and if the value of an independent variable is higher than 1 , this means that the effect of the relevant explanatory variables on dependent variable is positive; and if it is smaller than 1 , this means that the effect of the relevant explanatory variables on dependent variable is negative (Wooldridge, 2005; Baltagi, 2005; Greene, 2012).

According to the model results, women in the 26-35, 36-45 and 46-59 age group faced more physical and sexual violence than those in the 15-25 age group. Although those who were high school graduates faced less physical and sexual violence than those who did not attend any schools or who were primary school graduates, they faced more economic and emotional violence. Women who were university graduates or who had higher degrees faced less violence of any types. Employment of women did not have any effects on physical violence and economic or emotional violence. Working women faced more sexual violence than those who did not work; and if women had income or earnings of their own, they faced less economic and emotional violence. Women's having own income or earning did not have any significant effects on physical and sexual violence. On the other hand, in case women had health insurance (SSK, SGK, State Retirement Fund, Bag-Kur, private health insurance, etc.), it was determined that they faced less physical, sexual and economic and emotional violence when compared with the women who faced no violence. When the educational status of the husbands or intimate partners were analyzed, it was determined that those who were high school graduates applied less physical and sexual violence than those who did not attend any schools or who were primary school graduates; and those who were university graduates and who had postgraduate studies applied less violence of any types. Working status of the husbands did not have any statistically significant effects on violence against women in any of the models. In case the husband had bad habits like alcohol, gambling and drug use, it was determined that they applied more violence of any kind. Men who used alcohol applied more physical violence against women at a rate of 2 times, more sexual violence at a rate of approximately 3 times, more economic and emotional violence at a rate of 1.5 times; those who used drugs applied more physical violence to their wives at a rate of 4 times and applied more sexual violence at a rate of 7 times. Similarly, women whose husbands or intimate partners had gambling habits faced more physical violence at a rate of 5 times, more sexual violence at a rate of 8 times, and more economic and emotional violence at a rate of 2 times when compared with women who did not face any violence. When considered in terms of residential areas, it was determined that women living in urban areas faced more violence of any types when compared with women living in rural areas. If there are children between 6-14 years of age in the family, women faced more physical, sexual and economic and emotional violence. The empirical results of the study support the findings obtained by Kocacık et al., (2007), Altınay and Arat (2009), Yüksel-Kaptanoğlu et al., (2012), Büyükyılmaz and Demir (2016), Paul (2016) and Dasre et al. (2017). 
O. Ayvaz-Kizilgol - E. Ipek

Table 7. Multinomial Logit Model

\begin{tabular}{|c|c|c|c|c|c|c|c|c|c|}
\hline & \multicolumn{3}{|c|}{ Physical Violence } & \multicolumn{3}{|c|}{ Sexual Violence } & \multicolumn{3}{|c|}{$\begin{array}{c}\text { Economic and Emotional } \\
\text { Violence }\end{array}$} \\
\hline & Coef. & RRR & $\mathbf{P}$ & Coef. & RRR & $\mathbf{P}$ & Coef. & RRR & $\mathbf{P}$ \\
\hline \multicolumn{10}{|l|}{ Woman's age $^{1}$} \\
\hline $26-35$ & 0.432 & 1.540 & 0.000 & 0.569 & 1.767 & 0.001 & 0.776 & 1.081 & 0.461 \\
\hline $36-45$ & 0.492 & 1.635 & 0.000 & 0.459 & 1.582 & 0.011 & -0.009 & 0.991 & 0.938 \\
\hline $46-59$ & 0.701 & 2.017 & 0.000 & 0.811 & 2.250 & 0.000 & -0.046 & 0.955 & 0.665 \\
\hline \multicolumn{10}{|l|}{$\begin{array}{l}\text { Educational level of } \\
\text { woman }^{2}\end{array}$} \\
\hline High school & -0.384 & 0.681 & 0.000 & -0.306 & 0.736 & 0.031 & 0.168 & 1.183 & 0.067 \\
\hline $\begin{array}{l}\text { Graduated from } \\
\text { university and above } \\
\text { educational levels }\end{array}$ & -0.940 & 0.390 & 0.000 & -0.884 & 0.413 & 0.000 & -0.270 & 0.763 & 0.035 \\
\hline \multicolumn{10}{|l|}{$\begin{array}{l}\text { Employment status } \\
\text { of woman }\end{array}$} \\
\hline Working & 0.016 & 1.017 & 0.850 & 0.347 & 1.415 & 0.002 & 0.098 & 1.103 & 0.283 \\
\hline \multicolumn{10}{|l|}{$\begin{array}{l}\text { Woman has health } \\
\text { insurence }{ }^{4}\end{array}$} \\
\hline Yes & -0.210 & 0.810 & 0.037 & -0.251 & 0.778 & 0.051 & -0.223 & 0.799 & 0.030 \\
\hline \multicolumn{10}{|l|}{$\begin{array}{l}\text { Woman has own } \\
\text { income or earning }\end{array}$} \\
\hline Yes & 0.506 & 1.052 & 0.602 & -0.115 & 0.892 & 0.364 & -0.221 & 0.802 & 0.030 \\
\hline \multicolumn{10}{|l|}{$\begin{array}{l}\text { Educational level of } \\
\text { husband/partner }{ }^{2}\end{array}$} \\
\hline High school & -0.227 & 0.797 & 0.006 & -0.585 & 0.557 & 0.000 & 0.084 & 1.088 & 0.296 \\
\hline $\begin{array}{l}\text { Graduated from } \\
\text { university and above } \\
\text { educational levels }\end{array}$ & -0.554 & 0.575 & 0.000 & -1.098 & 0.334 & 0.000 & -0.283 & 0.753 & 0.009 \\
\hline \multicolumn{10}{|l|}{$\begin{array}{l}\text { Employment status } \\
\text { ofhusband/partner }\end{array}$} \\
\hline Working & 0.068 & 1.071 & 0.422 & -0.145 & 0.865 & 0.185 & 0.013 & 1.013 & 0.877 \\
\hline \multicolumn{10}{|l|}{$\begin{array}{l}\text { Husband/Partner } \\
\text { uses alcohol }{ }^{4}\end{array}$} \\
\hline Yes & 0.743 & 2.103 & 0.000 & 1.038 & 2.823 & 0.000 & 0.413 & 1.511 & 0.000 \\
\hline \multicolumn{10}{|l|}{$\begin{array}{l}\text { Husband/Partner } \\
\text { gambles }^{4}\end{array}$} \\
\hline Yes & 1.682 & 5.376 & 0.000 & 2.136 & 8.463 & 0.000 & 0.860 & 2.364 & 0.020 \\
\hline \multicolumn{10}{|l|}{$\begin{array}{l}\text { Husband/Partner } \\
\text { uses drug }{ }^{4}\end{array}$} \\
\hline Yes & 1.369 & 3.931 & 0.005 & 1.963 & 7.119 & 0.000 & -0.063 & 0.939 & 0.921 \\
\hline \multicolumn{10}{|l|}{ Place of residence ${ }^{5}$} \\
\hline Urban & 0.185 & 1.203 & 0.011 & 0.313 & 1.368 & 0.001 & 0.347 & 1.415 & 0.000 \\
\hline \multicolumn{10}{|l|}{ Child between 6-146 } \\
\hline Exist & 0.337 & 1.401 & 0.000 & 0.518 & 1.679 & 0.000 & 0.157 & 1.170 & 0.045 \\
\hline Constant & -1.105 & & 0.000 & -1.993 & & 0.000 & -0.803 & & 0.000 \\
\hline Hausman Test & \multirow{9}{*}{\multicolumn{3}{|c|}{$\begin{array}{c}-8322.8535 \\
0.0447 \\
6793\end{array}$}} & & & & & & \\
\hline$\chi^{2}(32)$ & & & & & & & & & \\
\hline Prob $>\chi^{2}$ & & & & & & & & & \\
\hline Wald Test & & & & & & & & & \\
\hline$\chi^{2}(24)$ & & & & & & & & & \\
\hline Prob> $\chi^{2}$ & & & & & & & & & \\
\hline Log Likelihood & & & & & & & & & \\
\hline Pseudo $R^{2}$ & & & & & & & & & \\
\hline Sample Size & & & & & & & & & \\
\hline
\end{tabular}

Note: The reference category of dependent variable is woman who are never exposed to violence. ${ }^{1} 15-25$ old, ${ }^{2}$ No education or primary school, ${ }^{3} \mathrm{Not}$ working, ${ }^{4} \mathrm{No},{ }^{5} \mathrm{Rural},{ }^{6} \mathrm{Absent}$, demonstrates the reference categories of relevant variables. 
MNLM is valid under the assumption of Independence of Irrelevant Alternatives (IIA). The Hausman test contains the statistical data on whether the MNLM fits the dataset or not. According to the Hausman Test results given in Table 7, it is clear that alternatives are independent from each other; in other words, the IIA assumption is valid, and the MNLM is applicable. The Wald test approximates the LR (Likelihood Ratio) test. Both of them exhibit similar outputs for restrictions related to explanatory variables. The Wald Test is used in this paper. The Wald test works by testing that the parameters of interest are simultaneously equal to zero. If they are, this strongly suggests that removing them from the model will not substantially reduce the fit of that model, since a predictor whose coefficient is very small relative to its standard error is generally not doing much to help predict the dependent variable. We tested whether the coefficients of the variables related to women (woman's age, educational level of woman, employment status of woman, health insurance of woman, woman's own income or earnings) are equal to zero. Based on the p-value of Wald test, we are able to reject the null hypothesis, again indicating that the coefficients for woman's age, educational level of woman, employment status of woman, health insurance of woman, woman's own income or earnings are not simultaneously equal to zero, meaning that including these variables create a statistically significant improvement in the fit of the model.

\section{Conclusion}

Domestic violence against women, which is an important social problem, does not only affect the physical and spiritual health of women, but it also prevents their development in terms of legal, social, political and economic status. The limited number of studies, providing detailed information and data on this topic, have posed major obstacles in the fight against domestic violence against women in our country. In Turkey, as well as some local studies related to this topic, a few national studies were also conducted in recent years. In this study, the factors that affected the probability of women facing violence within the family; in other words, the determinants of domestic violence against women, were analyzed by using the MNLM, which is one of the multiple choice models, by using the raw data of the "National Research on Domestic Violence against Women in Turkey" for the year 2014.

According to the empirical findings of the study, the most important factors that affected domestic violence against women were the educational levels of the women and their husbands, health insurance of the women, bad habits of husbands like alcohol, gambling and drug use, the area where the family resides and the presence of children between the age of 6-14. If the educational status of the women and their husbands was at and above university level, women faced less physical, sexual and economic and emotional violence. If women had health insurance, they faced less violence in all types. Women whose husbands used alcohol and drugs and had gambling habits faced more violence. Women whose husbands used alcohol faced more physical violence at a rate of 2 times, more sexual violence at a rate of 3 times, more economic and emotional violence at a rate of 1.5 times when compared with women who faced no violence at all. Women whose husbands used drugs faced more physical violence at a rate of 4 times, and more sexual violence at a rate of 7 times. Similarly, husbands who gambled applied more physical violence to their wives at a rate of 5 -times, more sexual violence at a rate of 8 times, more economic and emotional violence at a rate of 2 times. In the present study, the area where families resided were evaluated as urban areas and rural areas. Women living in urban areas were exposed to more violence than women living in rural areas. Having children between 6-14 years of age in the family was also determined to be an important factor increasing the violence against women. On the other hand, it was determined that the employment of husbands did not have any effects on any of the violence types. The age of women did not have any effect on economic or emotional violence. Another interesting result is that employment of women did not have any effect on physical violence and economic and emotional violence. However, it was observed that working women faced more sexual violence than women who did not work. Similarly, the income or earnings of women did not have any significant effects on physical and sexual violence. The empirical results obtained in the present study will contribute to the literature that lacks additional data in this field; and will be useful for public institutions and NGOs that fight against domestic violence against women in our country. 


\section{References}

Altınay, A. G., \& Arat, Y. (2009). Violence against women in Turkey, A nationwide survey. Istanbul: Punto Publishing Solutions.

Arı, E., \& Aydın, N. (2016). Examination by Multinomial Logistic Regression Model of the factors affecting the types of domestic violence against women: A case of Turkey. International Journal of Scientific \& Technology Research, 5(11), 67-74.

Baltagi, B. H. (2012). Econometric analysis of panel data (4. Edition). Wiley Press.

Beavers, S., \& Kumpf, B. (2013). Violence against women also hurts business and development. http://www.undp.org/content/undp/en/home/ourperspective/ourperspectivearticles/2013/03/29/violenceagainst-women-also-hurts-business-and-development.html (Access Date: 14 March 2018).

Buvinic, M., Morrison, A.R., \& Shifter, M. (1999). Violence in the Americas: A framework for action. (Ed.) Morrison A.R. \& Biehl M.L., Too Close to Home: Domestic Violence in the Americas. (pp.3-34). Washington DC: Inter-American Development

Bank. https://books.google.com.tr/books?id=aJXvZn5RUMcC\&printsec=frontcover\&dq=isbn:188693844X (Access Date: 14 March 2018).

Büyükyılmaz, A., \& Demir, Ç. (2016). Türkiye'de kadına yönelik aile içi şiddetin belirleyenleri: Multinomial logit model yaklaşımı. Ege Akademik Bakış, 16(3), 443-450.

Darıcı, B., \& Taşçı, H. M. (2015). Kendi hesabına çalışılan işler: Türkiye üzerine ekonometrik bir uygulama. Celal Bayar Üniversitesi iiBF Yönetim ve Ekonomi Dergisi, 22(1), 15-30.

Dasre, A., Greulich, A., \& Inan, C. (2017). Combating domestic violence against women in Turkey. The role of women's economic empowerment. Documents de travail du Centre d'Economie de la Sorbonne 2017.52 - ISSN: 1955611X. 2017. <halshs-01660703>

https://halshs.archives-ouvertes.fr/halshs-01660703/file/17052.pdf (Access Date: 14 March 2018).

Ergin, N., Bayram, N., Alper, Z., Selimoğlu, K., \& Bilgel, N. (2005). Domestic violence: A tragedy Behind The Doors. Women \& Health, 42(2), 35-51

Friedemann-Sánchez, G., \& Lovatón, R. (2012). Intimate partner violence in Colombia: Who is at risk? Social Forces, 91(2), 663-688

Greene, W. H. (2012). Econometric analysis (7. Edition). Boston: Pearson Education.

Hacettepe University Institute of Population Studies, (2014). Türkiye'de kadına yönelik aile içi şiddet araştırması özet rapor. http://www.hips.hacettepe.edu.tr/TKAA2014_Ozet_Rapor.pdf (Access Date: 16 January 2018).

Hausman, J., \& McFadden, D. (1984). Spesification tests for the multinomial logit model. Econometrica, 52, $1219-1240$.

Kocacık, F., \& Doğan, O. (2006). Domestic violence against women in Sivas, Turkey: Survey study. Public Health, 47, 742749

Kocacık, F., Kutlar, A., \& Erselcan, F. (2007). Domestic violence against women: A field study in Turkey. The Social Science Journal, 44, 698-720.

Ksuthan, T., Mwaba, S. O. C., \& Menon, A. (2016). Factors affecting domestic violence among married women in Zambia. British Journal of Education, Society \& Behavioural Science, 12(2), 1-13.

Long, J. S. (1997). Regression models for categorical and limited dependent variables. Thousand Oaks CA: Sage Publications.

Oktay, E.Y. (2015). Türkiye'nin ve dünyanın ortak sorunu: Kadına şiddet. Akademik Araştırmalar Dergisi, 64, 57-118.

Panda, P., \& Agarwal, B. (2005). Marital violence, human development and women's property status in India. World Development, 33(5), 823-850.

Paul, S. (2016). Women's labour force participation and domestic violence: Evidence from India. Journal of South Asian Development, 11(2), 224-250

Selim, S. (2008). Türkiye'de bireysel mutluluk kaynağı olan değerler üzerine bir analiz: Multinomial Logit Model. Çukurova Üniversitesi Sosyal Bilimler Enstitüsü Dergisi, 17(3), 345-358.

Sorenson, S. B., Upchurch, D. M., \& Shen, H. (1996). Violence and injury in marital arguments: Risk patterns and gender differences. American Journal of Public Health, 86(1), 35-40.

TURKSTAT, (2008). Türkiye'de kadına yönelik aile içi şiddet araştırması. Micro Data Set

TURKSTAT, (2014). Türkiye'de kadına yönelik aile içi şiddet araştırması. Micro Data Set 
UNICEF, (2000). Domestic violence against women and girls, innocenti digest, No:6, https://www.unicefirc.org/publications/pdf/digest6e.pdf (Access Date: 14 March 2018)

UNSTATS, (2015). The world's women 2015: Trends and statistics. New York: United Nations, Department of Economic and Social Affairs, Statistics Division. Sales No. E.15.XVII.8, Statistical Annex, https://unstats.un.org/unsd/gender/chapter6/chapter6.html (Access Date: 14 March 2018).

Yılmaz, O. (2017). Women's autonomy, social norms and intimate partner violence against women in Turkey. https://editorialexpress.com/cgi in/conference/download.cgi?db_name=ESPE2015\&paper_id=402 (Access Date: 14 March 2018).

Yüksel-Kaptanoğlu, İ., Türkyılmaz, A. S., \& Heise, L. (2012). What puts women at risk of violence from their husbands? Findings from a large, nationally representative survey in Turkey. Journal of Interpersonal Violence, 27(14), 27432769.

Wooldridge, J. M. (2005). Econometric analysis of cross section and panel data. MIT Press.

World Health Organization, (2017). http://www.who.int/mediacentre/factsheets/fs239/en/ (Access Date: 14 March 2018). 


\section{Appendix}

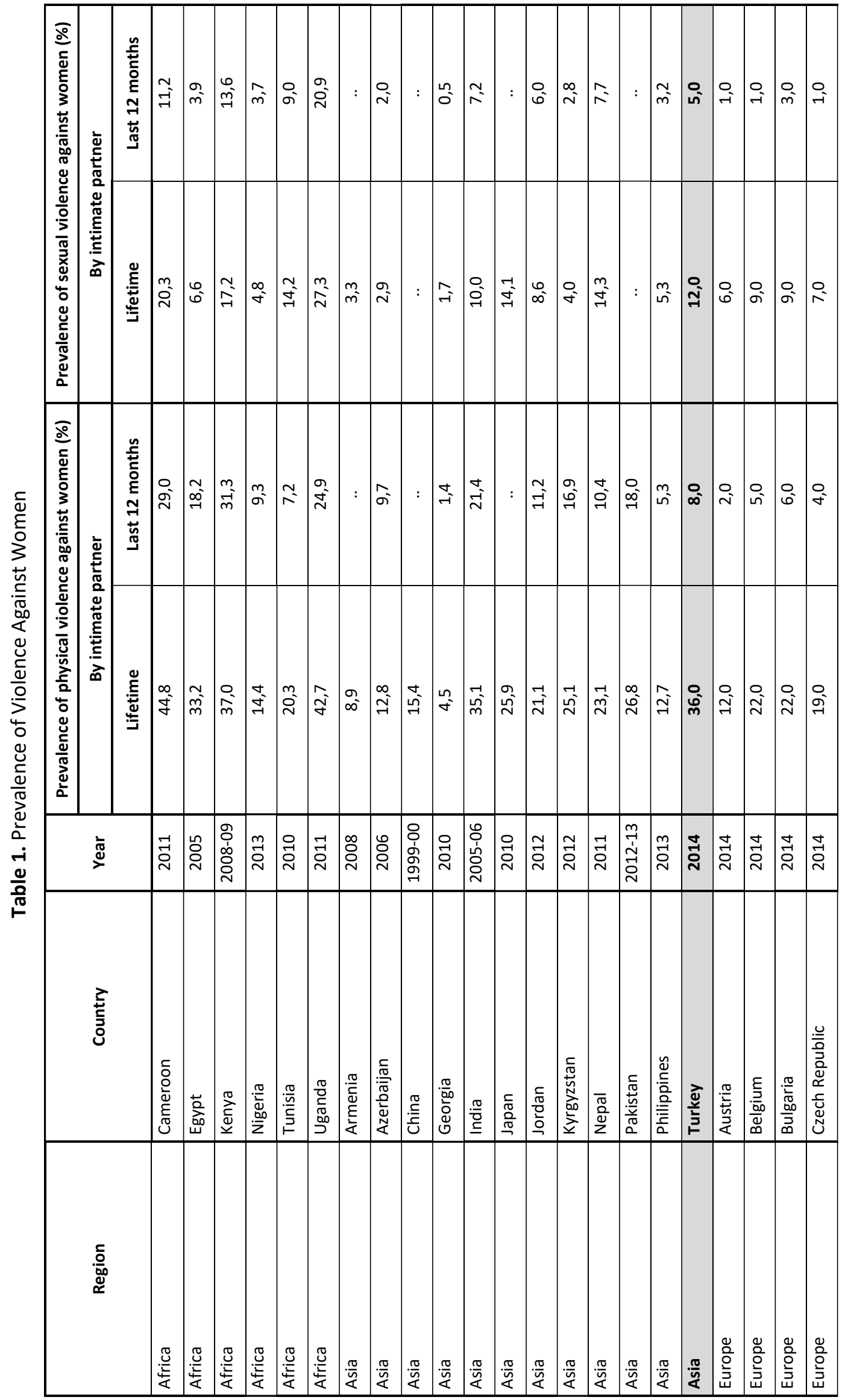




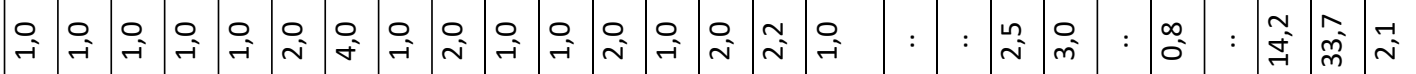

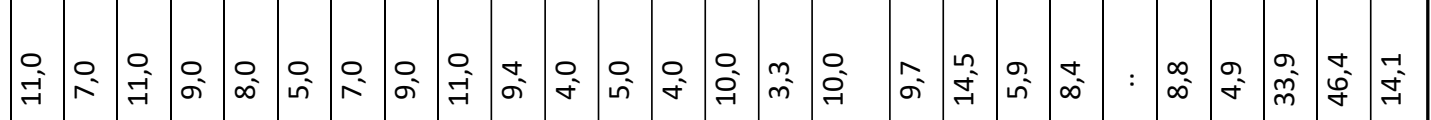

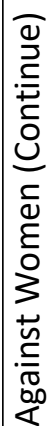

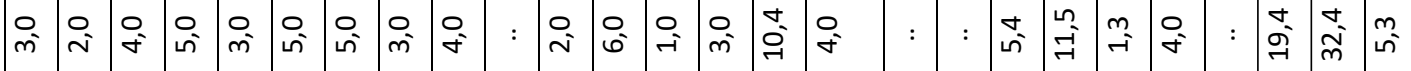

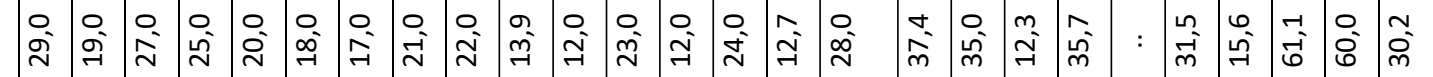

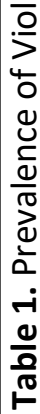

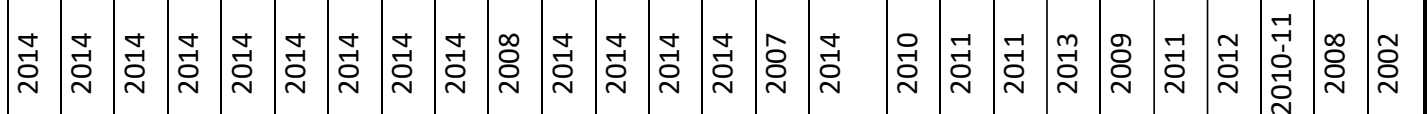

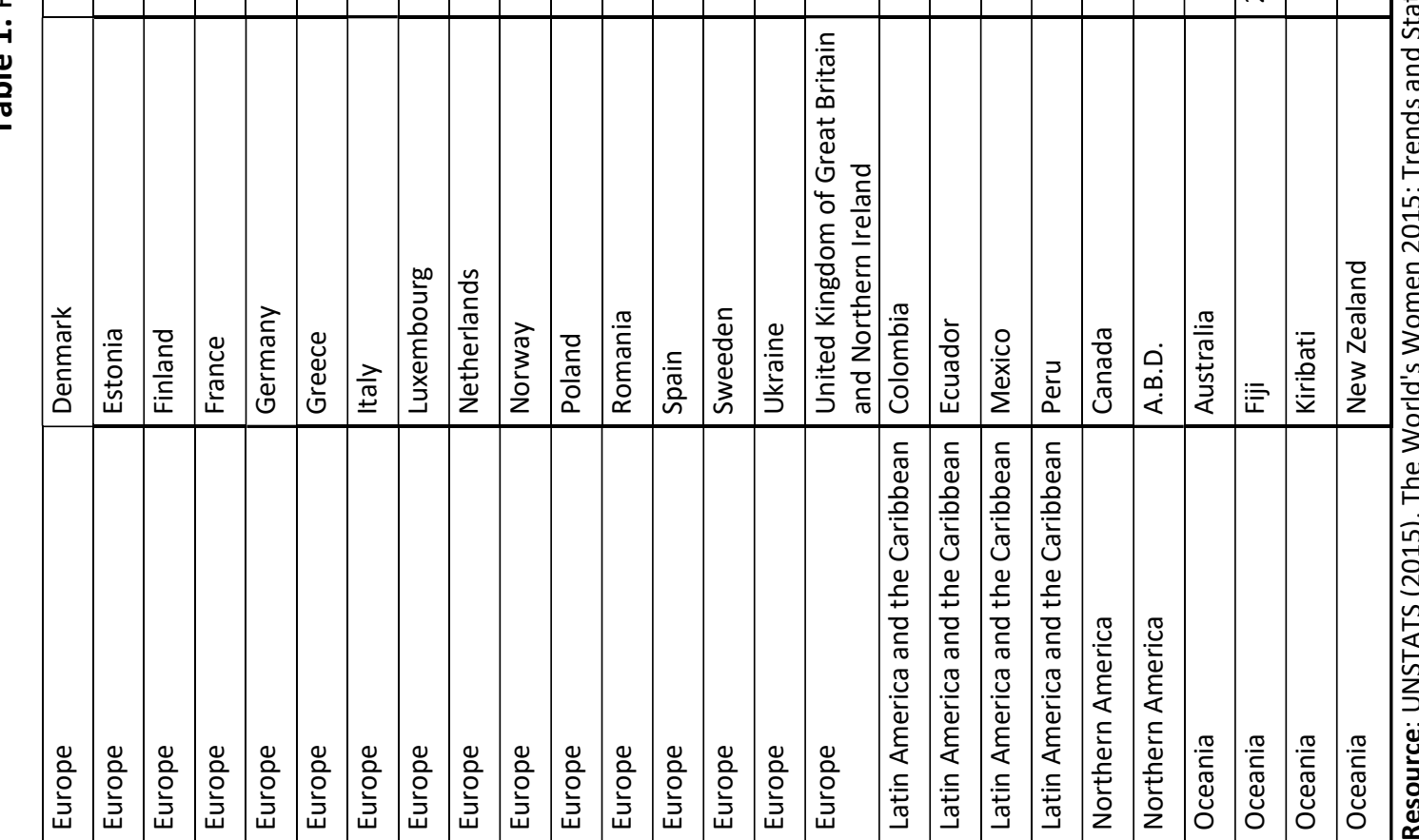




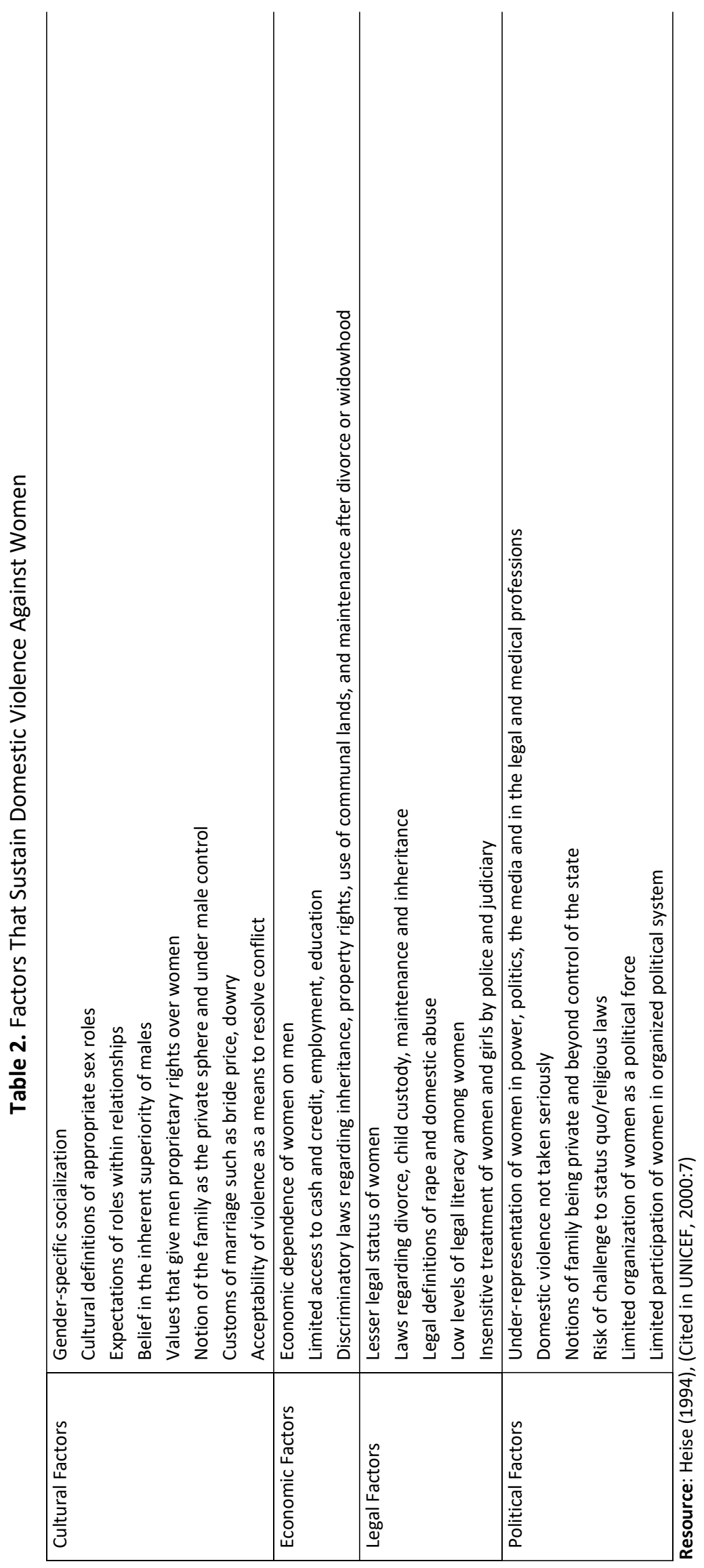




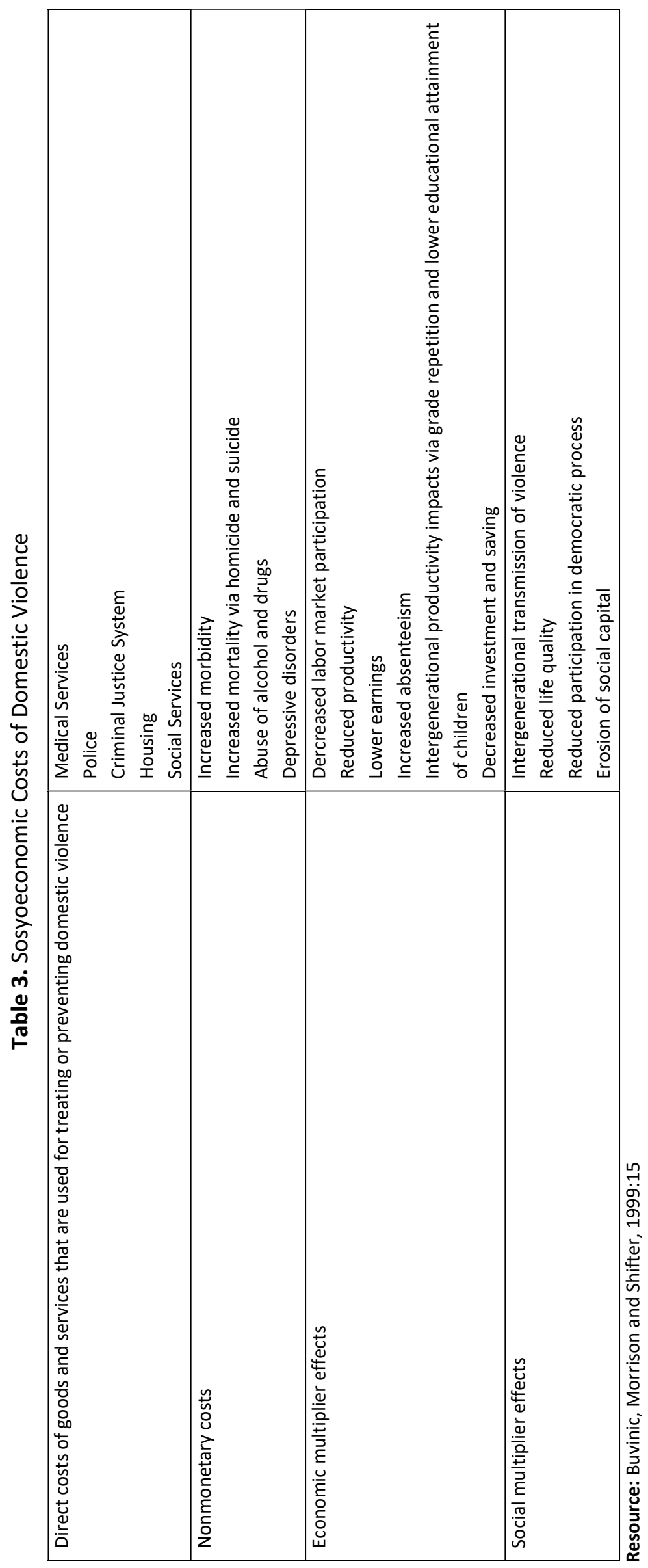




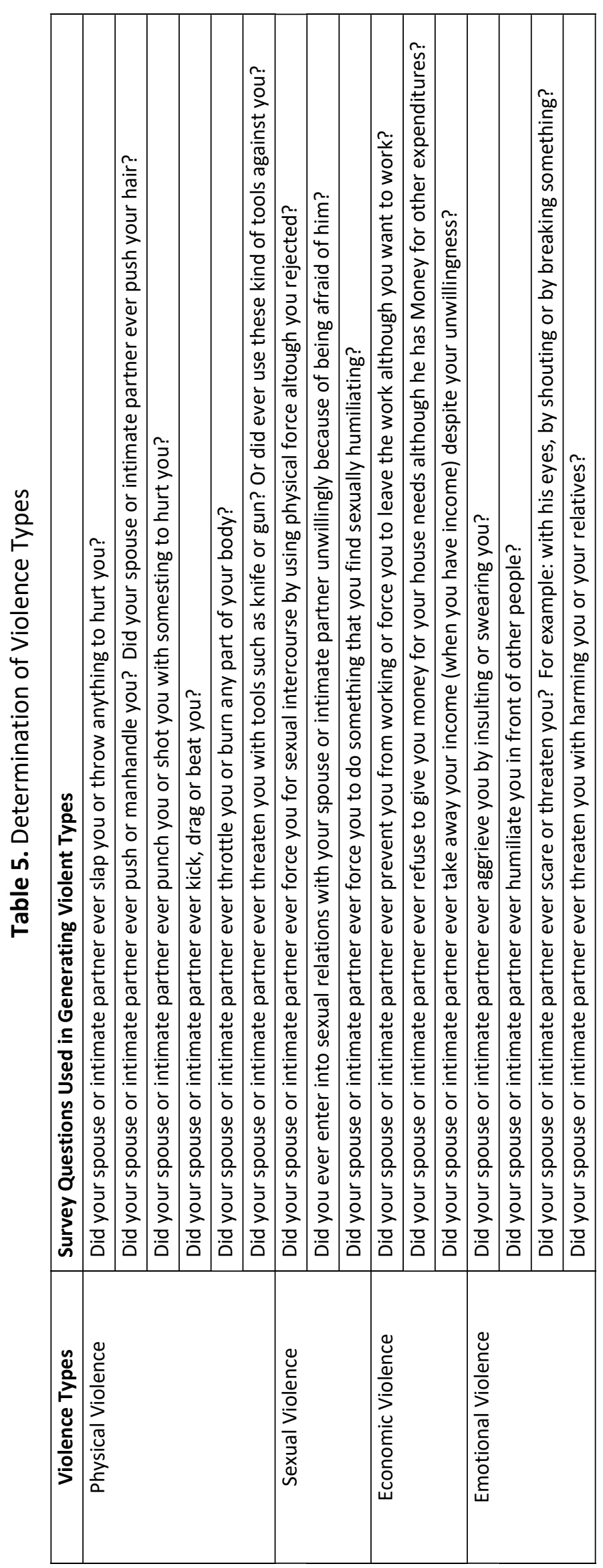


This Page Intentionally Left Blank 